\title{
Portfolio assessment in the frame of multi-layered peer coaching: An alternative portfolio for pre-service teachers
}

\author{
Siti Tarwiyah*, Nuna Mustikawati Dewi, Fatah Syukur \\ English Language Education Department, Faculty of Education and Teacher Training, \\ Universitas Islam Negeri Walisongo, Indonesia \\ Corresponding Author* \\ Email: sititarwiyah98@gmail.com \\ Received: \\ 4 February 2021 \\ Revised: \\ 1 March 2021 \\ Accepted: \\ 17 June 2021 \\ Published: \\ 31 August 2021
}

\begin{abstract}
Literature has shown that portfolio assessment is meaningful for supporting student-teachers' language and teaching skills. However, integrating portfolio assessment and Multi-layered Peer Coaching (MPC) is still scarcely done. To fill in this empirical void, this study elaborates the implementation of portfolio assessment in Micro Teaching class integrated with MPC. This is a case study with 22 pre-service teachers and one teacher educator as data sources. The data were collected through observation and documentation, and analyzed by using interactive model of analysis. It reveals that the artifacts of portfolio are dominated by collaboration-based products, comprising 13 artefacts. This portfolio may be developed to accommodate alternative assessment in Micro Teaching Class.
\end{abstract}

Keywords: portfolio assessment; Multi-layered Peer Coaching (MPC); preservice teachers; Micro Teaching class

\section{INTRODUCTION}

Building teacher capacity and professional culture is demanded to improve and sustain professional practices. In some schools, the former is still hard to obtain. The latter is even harder in those schools. This is due to the insensitivity of the teachers to some challenges which require the movement of their educational practices. Low quality of input, minimal resources and other supports, unsupportive socio-cultural background of students does not even stimulate them to strive to improve their professionalism. They may also be tired of making efforts to the learning improvement or they do not know what to do with all those problems.

Being a teacher is being a professional educator. Indonesian Law Number 20/2003 on National Education System states that educator is a professional with some duties such as planning and implementing learning process, evaluating learning outcomes, guiding and training students, and conducting research and community service, primarily for educators in higher education. 
Tarwiyah, S., Dewi, N. M., \& Syukur, F. (2021). Portfolio assessment in the frame of multi-layered peer coaching: An alternative portfolio for pre-service teachers. EduLite: Journal of English Education, Literature, and Culture, 6 (2), 270-286. http://dx.doi.org/10.30659/e.6.2.270-286

Those duties seem simple to spell but difficult to meet. The explicit statement requiring teachers to be professional suggests teachers' commitment to their tasks, consistency in their professional development.

Pre-service EFL teachers are expected to be professional teachers in their time. Through a range of activities, i.e. planning, implementing, assessing and evaluating an English lesson in Micro Teaching class, they are expected to be familiar with and skillful at their duties as teachers which ends up with being professional in their field. To reach the objective, the class needs to maximize the pre-service EFL teachers' active participation in class to engage in the planning, implementing, assessing and evaluating activities through reflective practices and peer learning.

Portfolio assessment appears to be an alternative assessment, which may support the pre-service teachers' engagement in Micro Teaching class. Its focus on selected document as the source of data of the pre-service teachers' teaching performance makes them consistent to complete the document. Portfolio assessment is a systematic collection of students' work that is analyzed to show progress over time regard to instructional objective (Valencia \& Calfee, 1991). It is one of the most popular forms of alternative assessment, which includes performance assessment, portfolios, and student self-assessment.

Portfolio assessment has strong power of self-evaluation for students and feedbacks for teachers (Bryant $\&$ Timmins, 2002). Anderson et al. (2001) assert educators not to forget the usefulness of portfolios and other performance assessments. A portfolio is a purposeful collection of the students' work that demonstrates to students and others their efforts, progress, and achievements in given areas. Portfolios include essays, compositions, reading logs, drawings, poetry, book reports, art video or audiotape recordings of a student's oral production, journals, teacher or student comments on progress made by students. Guidelines for using portfolios in a classroom are very much like the guidelines offered for journal writing.

Portfolios offer an innovative framework for assessment (Johns \& Van Leirsburg, 1992). It is due to the following essentials: it includes recording and the description of learners' learning experience in their own words. This description represents the learners' reflection, which is in fact the heart of the portfolio itself. A portfolio will only become a logbook if it is produced without reflection (Joshi et al., 2015).

Studies on portfolio implementation have been conducted. Matra \& Rukmini (2017) implemented e-portfolio in micro teaching class to sight its effect on the student teachers' teaching and reflective skills in the perspective of student teachers. Shaw (2017) described video recorded teaching activity of teacher candidates as portfolio in the micro teaching class of Central Washington University, which prepared the candidates to teach with accomplished skills, Efendi et al. (2017) proved the significant improvement of students' writing skills and their responses after portfolio assessment was implemented.

Portfolio in the frame of Multi-layered Peer Coaching (MPC) is uniquely implemented, since it is dominated by collaborative work. Encompassing such activities as pair-individual plan, experimentation, and reflection, (MPC) provides opportunity to the pre-service teachers to complete their reflective educational work in pairs before individual practices were done. MPC may equip 
the EFL teachers with pedagogical knowledge and content knowledge, which supported an effective EFL learning.

The combined implementation of MPC and portfolio assessment also signs the difference between this research and the previous research on the implementation of coaching. Among all of them are responsibility model as a model of coaching that acknowledges the learner's prior knowledge and experience (Collet, 2015), the examination of the dialogic competence of 5 Korean primary school English teachers in online peer coaching (Butler \& Yeum, 2016), the use of fictional characters to develop coaching practice (Eastman, 2016), the implementation coachee-centred coaching to promote teachers' pedagogical competence (Tarwiyah et al., 2018), study on the six "P" to overcome the challenges that inclusion coaches had with teachers as they transition into an inclusive service delivery model (Gallagher \& Bennett, 2018).

Coaching exposes intensive enlightenment on the subject of professional dialogue. Portfolio assessment depicts the pre-service teachers' competence and performance on the subject. This study is aimed at describing the implementation of portfolio assessment in Micro Teaching in the frame of Multilayered Peer Coaching.

\section{METHOD}

This study is a case study. Case study is a study focusing on a contemporary phenomenon which does not need the control from the researcher (Yin, 2003). The researcher explored the phenomenon of portfolio assessment and Multilayered Peer Coaching in a Micro Teaching class. The research participants were 1 teacher educator and 22 pre-service EFL teachers.

Data were collected through observation and documentation. The observation was done within 14 meeting class. The documents accessed were samples of students' portfolio. The data were analyzed using 5 steps of interactive model of analysis, i.e. (1) collecting data; (2) classifying data; (3) reducing data; (4) displaying data, and; (5) drawing concluding or verifying (Miles \& Huberman, 1994).

\section{RESULTS AND DISCUSSION}

The implementation of portfolio assessment within MPC was staged into 3, i.e. (1) pre-course, (2) main course, and (3) post course.

\section{Pre-Course}

In the pre-course, after being enlightened with the concepts of portfolio as a part of authentic assessments the participants were required to complete questionnaire assessing their self-preparedness before joining the class. They were, then, asked to write their learning targets within one semester. All participants were free to set their goal of learning and their strategic plans to reach the goals. In addition, the pre-service teachers were also assigned to write $\mathrm{CV}$. By the end of the semester, the participants compared the progress of their experience covered in the first with the second CV, the progress of their preparedness after completing the second questionnaire, and checked the achievement of the learning targets. To sum up, in the pre-course 3 artifacts were completed, i.e. (1) pre-course self-preparedness questionnaire, (2) targets 
Tarwiyah, S., Dewi, N. M., \& Syukur, F. (2021). Portfolio assessment in the frame of multi-layered peer coaching: An alternative portfolio for pre-service teachers. EduLite: Journal of English Education, Literature, and Culture, 6 (2), 270-286. http://dx.doi.org/10.30659/e.6.2.270-286

of learning, and (3) pre-course CV. The artifacts were prepared individually. Below is the sample of learning targets:

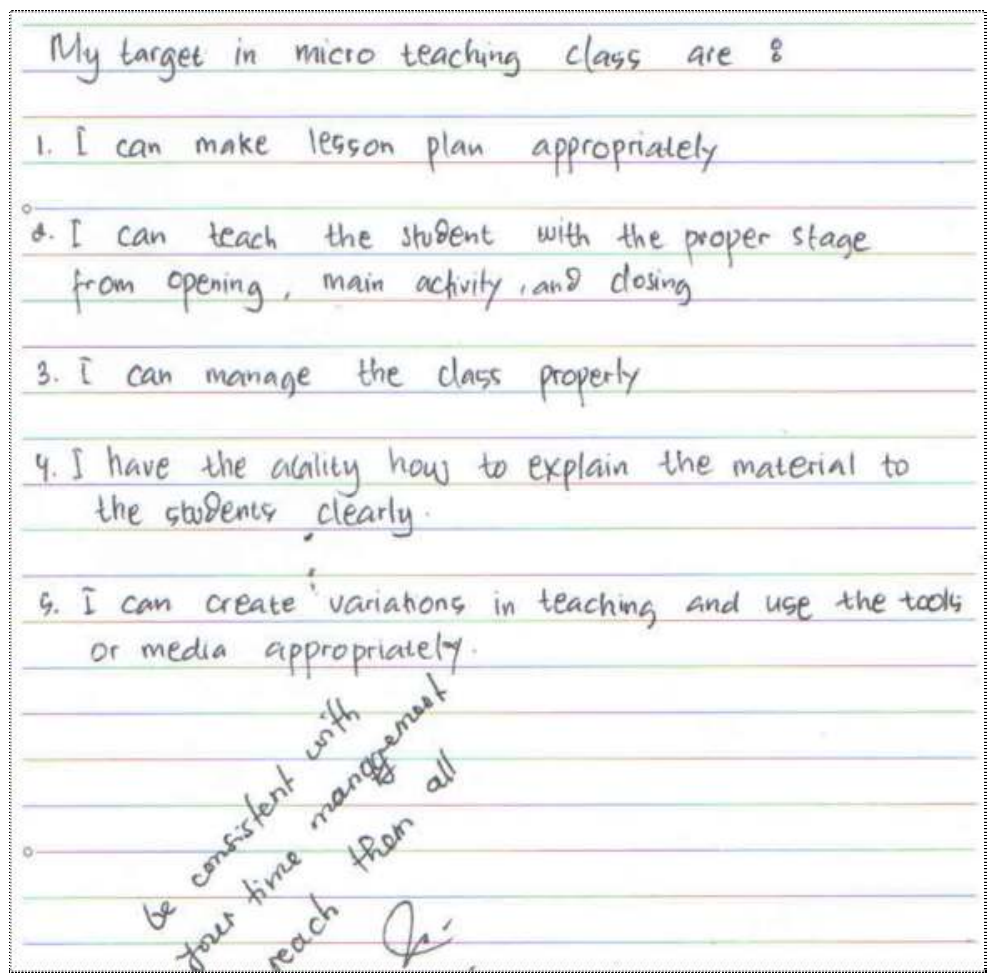

Figure 1. Sample of learning target

The formulation is too practical, compared with the indicators of teacher's pedagogical competence as mentioned in the addendum of Indonesian Ministerial Decree Number 16 Year 2007 on teachers' qualification and academic competence. The document mentions the indicators of pedagogic competence as follow:

1. Mastering the physical, moral, social, cultural, emotional, and intellectual characteristics of learners.

2. Mastering the theories and principles of educating learning.

3. Developing the curriculum of the managed subject.

4. Administering educating learning.

5. Implementing information and communication technology in learning.

6. Facilitating the development and the actualization of learners' potential.

7. Communicating effectively, emphatically, and politely with learners.

8. Employing the assessment and evaluation of process and product of learning.

9. Using assessment and evaluation for learning purposes.

10. Doing reflective actions to enhance the quality of learning.

If it is seen closely, it results in the description showing how each target is related to the indicators. 


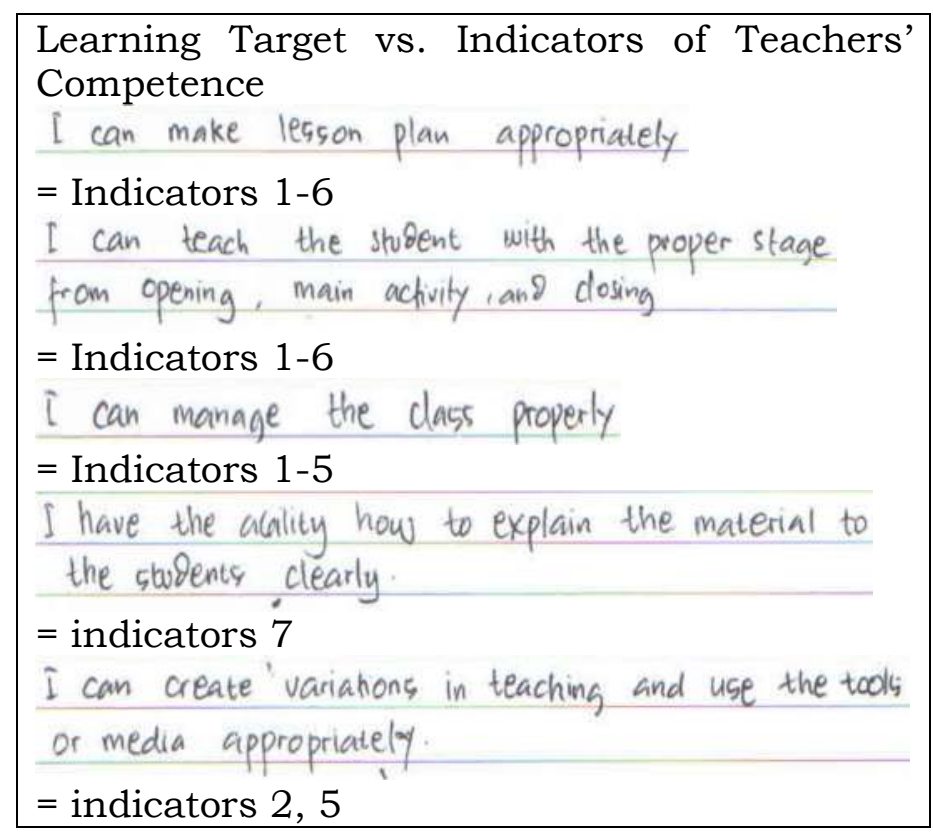

Figure 2. Learning targets

Indicators 8-10 are left uncovered. The analysis shows us how teacher educator should have commented on the portfolio. She should have reminded the preservice teacher the critical areas of pedagogic competence which are not covered in her targets of learning so that comprehensive targets were set.

\section{Main Course}

Six portfolios were accomplished in the main course, i.e. observation of the demonstration of eight basic skills in teaching and teaching methods, correction of lesson plan, reflection of teaching demonstration, lesson learnt 1, and lesson learnt 2 .

\section{Observation of the Demonstration of Eight Basic Skills in Teaching and Teaching} Method

Twenty two participants were divided into 11 pairs. They were given hands out containing some keys to demonstrate each of the 8 basic skills in teaching and teaching methods. 8 pairs demonstrate 8 skills and 3 pairs demonstrated 3 methods, i.e. Problem-Based, Project-Based, and inquiry learning. After presentation and demonstration, the whole class discussion was carried out in the form of 'teacher's time out activity'. The sample of portfolio is presented in figure 3. 
Tarwiyah, S., Dewi, N. M., \& Syukur, F. (2021). Portfolio assessment in the frame of multi-layered peer coaching: An alternative portfolio for pre-service teachers. EduLite: Journal of English Education, Literature, and Culture, 6 (2), 270-286. http://dx.doi.org/10.30659/e.6.2.270-286

3. INQUIRY LEARNING

\begin{tabular}{|c|c|c|c|}
\hline \multirow{2}{*}{ COMPONENTS } & \multicolumn{2}{|c|}{ IDENTIFICATION } & \multirow[t]{2}{*}{ NOTES } \\
\hline & Y & $N$ & \\
\hline $\begin{array}{l}\text { Seeking truth, information, or } \\
\text { knowledge by questioning. } \\
\text { Questioning is the key. }\end{array}$ & $\checkmark$ & & teacher askes students soote guestion \\
\hline $\begin{array}{l}\text { Teacher introduces topic by } \\
\text { developing a table, chart, picture, } \\
\text { or quick questionnaire }\end{array}$ & & & $\begin{array}{l}\text { teacher gives example from a roal model } \\
\text { (a nurse) }\end{array}$ \\
\hline $\begin{array}{l}\text { Students formulate some questions } \\
\text { about the topic }\end{array}$ & $\checkmark$ & & $\begin{array}{l}\text { Sodent asks some questions about } \\
\text { nurse }\end{array}$ \\
\hline $\begin{array}{l}\text { Students select the main question } \\
\text { that they find the most intriguing }\end{array}$ & $\checkmark$ & & $\begin{array}{l}\text { Sudents ask abbout how long she works } \\
\text { there, the age \& where she live }\end{array}$ \\
\hline $\begin{array}{l}\text { pairs of students meet to exchange } \\
\text { ideas and assist each other }\end{array}$ & & & $\begin{array}{l}\text { teacher askes students to watch video and } \\
\text { find the puain character then describe it. }\end{array}$ \\
\hline Students arrange report & $\checkmark$ & & students arrange the report on Goush stridents wor \\
\hline $\begin{array}{l}\text { Students present projects or } \\
\text { research papers to the ciassroom in } \\
\text { a variety of ways. }\end{array}$ & & & One shodent present the project \\
\hline $\begin{array}{l}\text { Students to evaluate their own } \\
\text { learning through reflection. }\end{array}$ & $\checkmark$ & & teacher asks stodents the difficuff material \\
\hline
\end{tabular}

Figure 3. Observation sheet of teaching method demonstration

The documents show keys of the implementation of problem-based and inquiry learnings. Nevertheless, the sentences used by the student to note the observation report, to some extents is confusing. 'A project' in feacher provides a project in the first note of inquiry learning means 'a problem'. 'Some questions', in teacher ash sidents sole question refers to stimulating questions. The terms used by the pre-service teachers in completing the notes suggests that their pedagogical literacy still needs to be improved.

Through the completion of checklist, it is expected that the pre-service teachers are aware of the implementation of each demonstrated model. The completion of the notes, besides checklist trains them to work with responsibility, sharpen their pedagogical analysis and awareness.

\section{Correction of Lesson Plan}

Before demonstrating a pair mini teaching, each lesson plan was corrected by another peer and teacher educator. Pair correction was done for pair teaching, individual correction was conducted for individual teaching. The revised lesson plan was, then, used in the teaching demonstration. The notes of correction from peer and lecturer were given to the owner of the lesson plan for the reference of correcting the lesson plan. After revision was done, the notes of correction from lecturer were put in the owner's portfolio, as it represented the owners' work. Meanwhile, the notes of correction from peer were put in the correctors' portfolio, as it was considered representing the correctors' accuracy and sensitivity in correcting a lesson plan. The notes of correction were shared in the class in order to be responded by the other participants and the lecturer.

Teacher is not the only agent of assessment. Assessment may also be done by students through peer-editing group, correction (Musarokah \& Egar, 2017; Yussuf et al., 2016), peer assessment (Mubarok, 2017). Peer correction is useful 
Edulite Journal of English Education, Literature, and Culture Vol. 6, No. 2, August 2021, pp. 270-286

E-ISSN: 2528-4479, P-ISSN: 2477-5304

http://jurnal.unissula.ac.id/index.php/edulite DOI: http://dx.doi.org/10.30659/e.6.2.270-286

means to involve the whole class in correction practice. If we ask a question to a specified student and the student gives the wrong answer, we should firstly always give chance to the student to self-correct. If this fails, rather than give the correct answer ourselves we may simply ask another student instead. Through peer correction teacher also can check what the rest of the students understand. If it becomes the fact that no one in the class really understands, teacher explores where the problem lies then the appropriate steps are taken to make sure the understanding of everyone.

Below is the sample of students' portfolio showing how they corrected their peer's lesson plan.

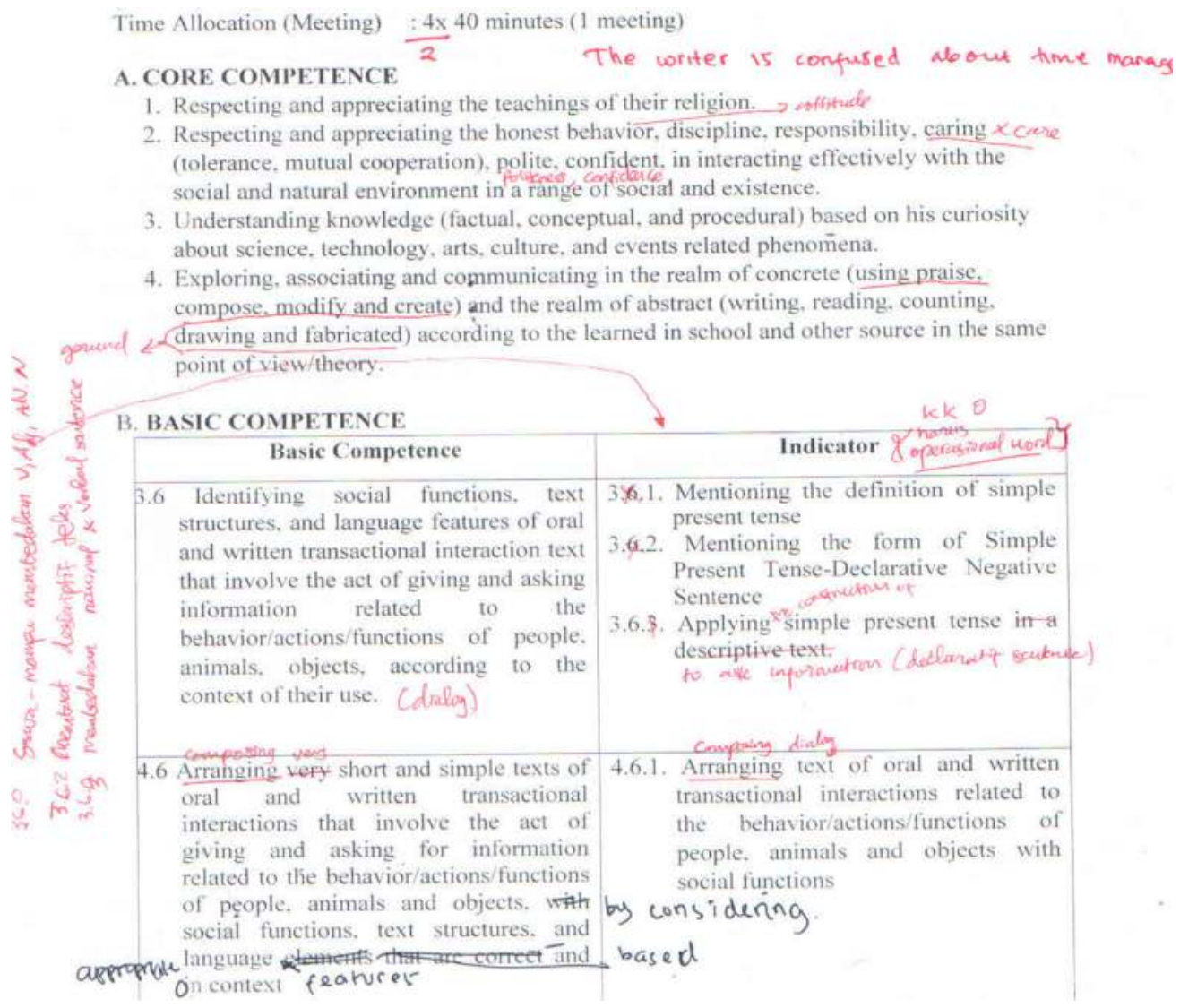

Figure 4. Sample of peer corrected lesson plan

A relatively thorough correction had been made by two correctors. Below is the list of corrected and uncorrected components of the part of the lesson plan. CC stands for Core Competence and BC represents Basic Competence of English subject for the seventh grade of Junior High School in Indonesian 2013 Curriculum. 
Tarwiyah, S., Dewi, N. M., \& Syukur, F. (2021). Portfolio assessment in the frame of multi-layered peer coaching: An alternative portfolio for pre-service teachers. EduLite: Journal of English Education, Literature, and Culture, 6 (2), 270-286. http://dx.doi.org/10.30659/e.6.2.270-286

Table 1. Corrected and uncorrected components

\begin{tabular}{|c|c|}
\hline Corrected & Uncorrected \\
\hline Time allocation: s/b 2 x 40 & $\begin{array}{l}\text { Using singular for plural noun, i.e. } \\
\text { 'sentence' in main material }\end{array}$ \\
\hline $\begin{array}{l}\text { CC 2: 'behavior' s/ / b 'attitude', using } \\
\text { noun for attitudes }\end{array}$ & CC 2: 'social' s/b 'society' \\
\hline 'fabricated's/b 'creating' & CC 3: 'related's/b 'related to' \\
\hline $\begin{array}{l}\text { BC 4.6: indicator 4.6.1: arranging s/b } \\
\text { composing }\end{array}$ & $\begin{array}{l}\mathrm{CC} 4 \text { : 'the learned' } \mathrm{s} / \mathrm{b} \text { 'the learned } \\
\text { materials', other source } \mathrm{s} / \mathrm{b} \text { 'other } \\
\text { sources' }\end{array}$ \\
\hline BC 4.6: 'with's /b 'by considering ....' & $\begin{array}{l}\text { Indicator 3.6.1: 'the definition' } \mathrm{s} / \mathrm{b} \\
\text { 'the function' }\end{array}$ \\
\hline $\begin{array}{l}\text { BC 4.6: 'compose' is more appropriate } \\
\text { since BC } 4 \text { focuses on skill } \\
\text { competence }\end{array}$ & $\begin{array}{l}\text { BC } 4.6 \text { : wrong correction, 'the' should } \\
\text { not be put before 'language' }\end{array}$ \\
\hline
\end{tabular}

\section{Observation of Teaching Demonstration}

Revising the pre-service teachers' understanding of process skills, i.e. planning, implementing, assessing and evaluating a lesson reminds the pre-service teachers to consider every aspect and indicator of the skills in their teaching practice so that being communicative, collaborative, creative, critical can be reached.

Ideally, teaching practice is planned, developed, and evaluated collaboratively (McGrane \& Lofthouse, 2010: 188). It is due to giving space to the pre-service teachers to peer-learn. That statement implies the importance of peer correction as the form of indirect collaborative plan and development, which was also implemented in this study.

The effectiveness of peer correction was also proven by Joh (2019). Fifty two Korean college students majoring in TEFL were studied at the beginning and the end of the semester with the purpose of identifying the possible change of their perception after practicing of peer feedback activities. An interview showed that peer feedback gave meaningful impacts on varied aspects of learning. Students who gained more exposure to peer feedback activities tended to be more favorably appreciate the meaningful impacts, especially on learning achievement. Peer feedback also minimized the difference of learning motivation between the extroverted and the introverted significantly. The results suggested the benefits of peer feedback for any personality type of learners.

Peer observation was done for mini teaching demonstration. Observation is an essential activity to sensitize the pre-service teachers with good and bad sides of mini teaching practices. Good observation helped them write comprehensive reflection. Teaching observation gave the pre-service mini teachers opportunity to get meaningful and direct feedback about their teaching performance. They might also be informed the development of resources to help them address the areas for improvement.

Although the participants had been provided detailed indicators of implementing competence which were also used as observation guidelines, their observation reports are far from complete. Figure 4 is an example of observation report showing the sharpness of a pre-service teacher's observation. 


\section{Report of Observation on Pair Mini Teaching}

1. Object:

Ani Fitriani

Hesti Rindhi Anggraeni

2. Topic: Descriptive Text

3. Result:
a. The opening step was done well, but there was a step that was skipped that is not explaining how the previous material is related to the previous one
b. They gave instructions to students quite clearly
c. In the main activity, learning activity is systematically implemented
d. They used Power Point as the tool in learning activity to show the text
e. They carried out the closing step well
f. The partition of tasks between the pair in carrying out mini teaching was uneven -

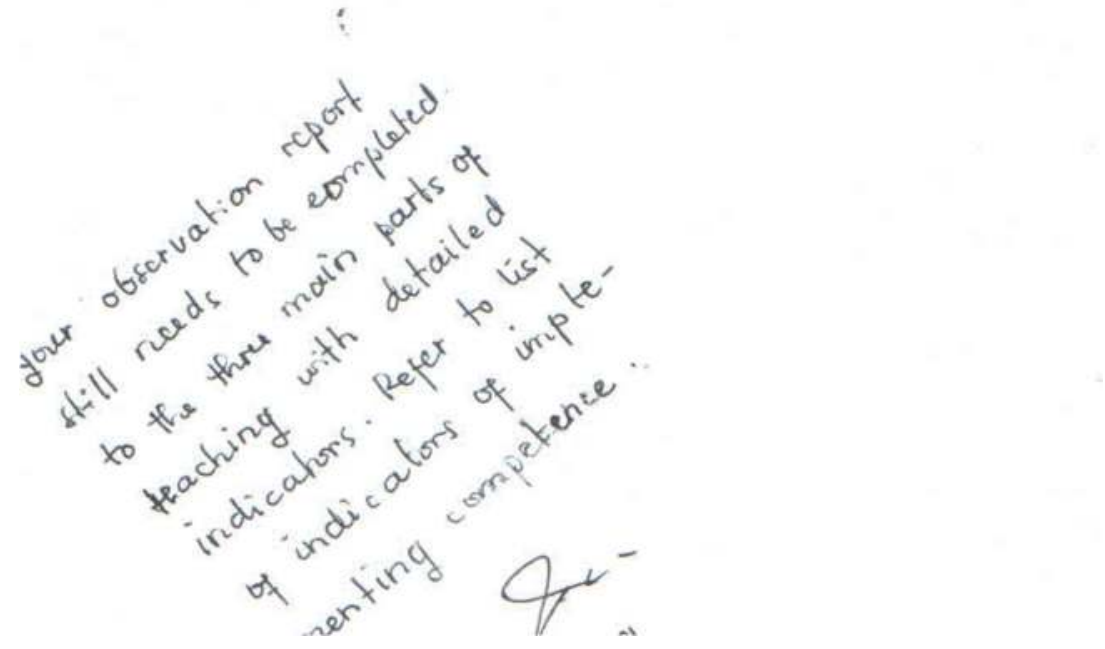

Figure 5. Sample of observation report

Although considerably comprehensive, but the report is too concise. It is like a summary written without evidence. Judgement without proof may be seen as claim. A poor observation report does not give clear description about what the class is like.

\section{Reflection of Teaching Demonstration}

Reflection is an essential part of professional development. Reflection bears the ideas of what skills still need to be improved and how to improve them in order to be professional. Reflection should cover planning, implementing, assessingevaluating stages.

Below is the example of a pre-service teacher's reflection written after his mini teaching demonstration. The reflection is so simple and does not cover all the three stages. 
Tarwiyah, S., Dewi, N. M., \& Syukur, F. (2021). Portfolio assessment in the frame of multi-layered peer coaching: An alternative portfolio for pre-service teachers. EduLite: Journal of English Education, Literature, and Culture, 6 (2), 270-286. http://dx.doi.org/10.30659/e.6.2.270-286

a. I did all the steps in the opening step, except for the scope of assessment.

b. I taught too teacher-centered, not student-centered

c. There must be improvements in the learning steps

d. I give unclear instructions to students

e. I still feel nervous when giving material to students

f. I have not carried out all the steps in the closing step, but only a few steps

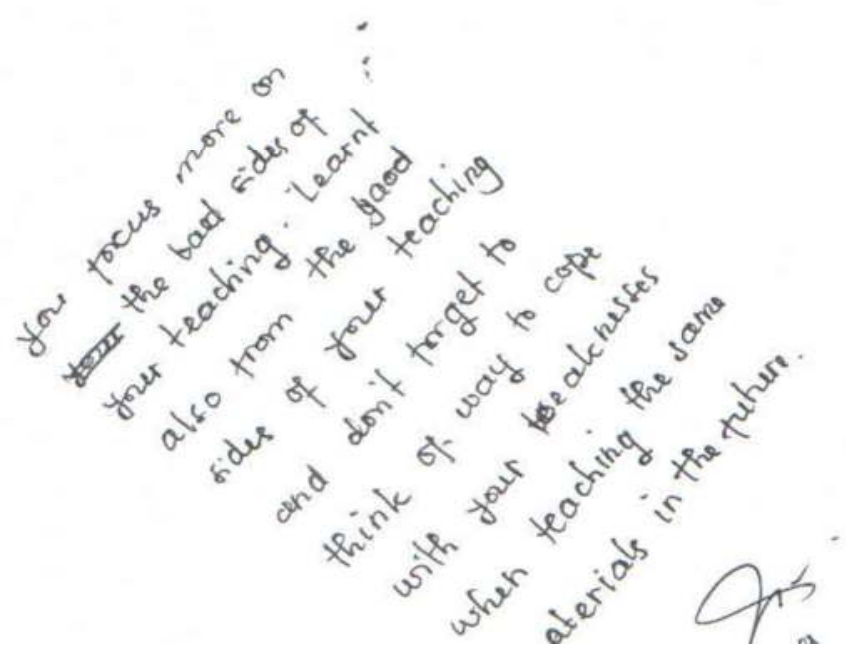

Figure 6. Sample of Teacher Reflection

Reflection is an inseparable part of a mini teaching demonstration. Reflection makes the pre-service teachers aware of their strengths and weaknesses in their teaching. It sensitizes teachers with policies for the coming teaching. "... reflection ... will help effective teachers when planning and evaluating their teaching by discussing pedagogical issues in their teaching" (McGrane \& Lofthouse, 2010, p. 188).

When writing a reflection the pre-service teachers forgot to describe briefly their teaching learning process. Ideally, a teaching reflection comprises introduction: giving brief description about teaching learning process, analysis: identifying the strengths and the weaknesses of the teaching, evaluation: formulating plan for the future learning when teaching the same materials in the future.

Reflection in figure 5 misses introduction and evaluation. Analysis is also partially made since it does not cover all the indicators of implementing and assessing-evaluating competence. Although strengths and weaknesses has been partially identified, the identification is provided without proof. The absence of evidence is something which needs attention. A reminder needs to be given to the writer as the presence of proof also represents the writer's responsibility for all judgements covered in the reflection.

Boody (2008, as cited in Rerung, 2013) mentions four levels of teacher reflection: (1) retrospective analysis reflection (ability to self-access), (2) teacher problem solving process reflection (awareness of how one learns), (3) critical selfreflection (developing continuous self-improvement), and (4) reflection on beliefs about the self, how someone plans, delivers, and evaluates his teaching is tightly 
influenced by his belief towards himself and others. Most of the pre-service teachers' reflections fall into the second category. They focused more on their students' responses, engagement, interest, difficulties than on the investigation of the appropriacy of their instruction, media, method, implementation, etc. Familiarizing with that kind of reflection does not train the pre-service teachers to self-evaluate, improve their weaknesses.

Meanwhile, in his study on the practice of critical reflective teaching in EFL class, Rerung (2013) found three categories of teacher reflection, i.e. (1) Introductory level, in which teachers saw things happened in the classroom as the effective indicators of their teaching progress, (2) Intermediate level, in which the teachers are conscious with their weaknesses in teaching, aware of the importance of feedback from their students, colleagues, and supervisors for their teaching betterment, (3) Advanced level, in which the teachers were able to identify rooms for improvement in their teaching, tried to learn from their past teaching experiences and came up with useful strategies to teach more effectively. Although they made reflection on their daily teaching, they did not substantially prepare their classes under systematic plan.

\section{Lesson Learnt 1}

Lesson Learnt 1 comprises notes of learning from a teaching practitioner of a school. In the middle of the semester, an EFL teacher of a Senior High School was invited. He shared his teaching experiences at his school. The purpose of inviting the teacher was to expose the preservice teachers with contextual issues dealing with process skills. It was expected that they would be aware of the gap between some teaching concepts and real teaching.

Figure 7 is the examples of notes on the lesson learnt from the teaching practitioner.

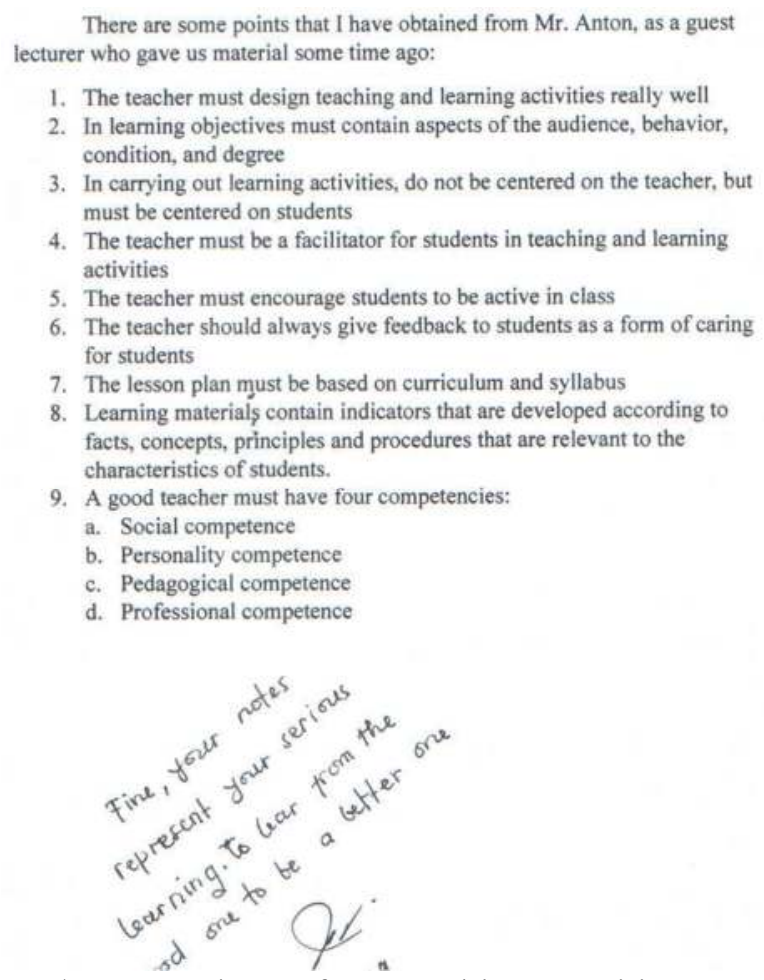

Figure 7. Lesson learnt from teaching practitioner 
In his presentation, he reviewed the characteristics of learning of 2013 curriculum, the components of lesson plan, and the way to give feedbacks to their peer's teaching demonstration. Feedback giving needs to cover all stages of learning and aspects of demonstration, i.e. opening, main activities, closing, materials, methods, media, and assessment. As the representation of appreciation, feedback is given by first, highlighting the good sides of the demonstration before critically judge the weaknesses of the teaching.

\section{Lesson Learnt 2}

Three students of the seventh semester were invited. They had just completed their teaching internship in Thailand. They shared their teaching experiences in the country, highlighted the differences of learning system they found. The purpose of inviting them was to trigger the pre-service teachers in order to be motivated to build their professionalism through joining some challenging activities as internship abroad, volunteering programs, etc. Picture 4.16 is the example of student' notes on the matter.

There are some lessons that I get from the explanation of the teaching experience delivered by Mas Mahrus and friends. In teaching English, the teacher must understand the conditions of students such as cultural conditions and the ability of students to learn, especially teaching in a place that has a different culture from the origin country. The teacher is also required to be active in delivering the material and becoming a facilitator to students. The teacher must also prepare anything that is needed in the learning activities properly even with a busy schedule. The teacher must seriously notice the material that will be delivered to students even though there are no provisions in making lesson plans as happened in Vietnam. In Vietnam, the duration of learning is longer than in Indonesia, they start learning activities from 7 am to $5 \mathrm{pm}$ in the afternoon so teachers must be able to maintain their health. The teachers there are always monitored by the manager so that the quality of the teachers can be maintained.

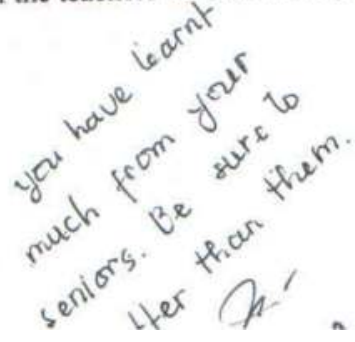

Figure 8. Lesson learnt from senior

\section{Post Course}

After joining a sequence of activities exposing the concepts and demonstrating the skills covering eight basic skills in teaching, teaching methods, process skills, and literacy in EFL class, the participants did the following activities: identifying the achievement of learning targets, identifying their selfpreparedness, making second curriculum vitae, doing class reflection. Two samples of portfolio artifacts are provided in figure 8 and 9. 
EduLite Journal of English Education, Literature, and Culture Vol. 6, No. 2, August 2021, pp. 270-286

\section{Identifying the Achievement of Learning Targets}

Identifying the achievement of learning targets is a part of reflection. After setting the targets of learning in the beginning of the course, joining the course within one semester, the participants identified the achievement of the targets. Below is the example of the identification.

1. I expect $I$ can plan appropriate teaching and learning activity for students. On this target, I am still trying to achieve it, there is little progress in this case, which at first I did not really know how to plan these activities well, finally with the help of corrections from lecturers and help from friends, finally I understood how to make plans learning well

2. I expect I can prepare well the appropriate teaching and learning activity for students.

On this target, it seems that I should try harder to achieve it, I should be better at preparing for teaching and learning activities.

3. I expect I can practice well the appropriate teaching and learning activity for students.

On this target, I think I have not achieved it optimally, because I was not optimal in preparing for teaching and learning activities and there were still many mistakes in practicing it, I had to try again to achieve it

4. I expect I can improve my confidence when I perform the teaching and learning.activity.

On this target, I feel I have achieved this target, I am able to increase my confidence when carrying out teaching and learning activities, although there are some mistakes.

5. I expect I can develop my skills in teaching students.

On this target, I feel I have achieved this target, I am able to improve my skills in teaching students, although it still needs to be improved to be better in teaching practice.

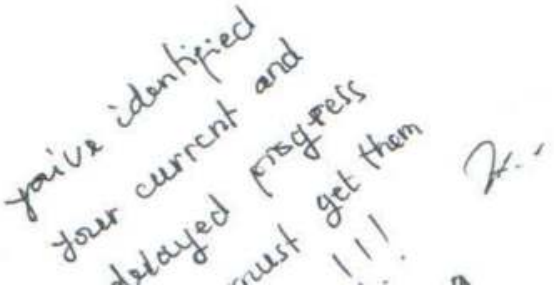

Figure 9. The Achievement of Learning Target

The above identification also represents the pre-service teacher's reflection. Below are the points of achievement:

1. The lecturer's and the peers' feedbacks supported the development of the pre-service teacher's planning competence. He could plan his mini teaching better, based on his target.

2. The improvement of planning competence was not supported by good preparation. As the result, he could not demonstrate his mini teaching based on his plan.

3. The familiarity of the pre-service teacher with the lecturer's and the peers' feedbacks, his positive response to the feedbacks brought the advancement of his confidence in demonstrating mini teaching. Although he still felt some weaknesses in teaching, the micro teaching class had really culturalized lecturer's and peers' feedbacks.

4. The pre-service teacher also made some improvement in his teaching skill. It implied the improvement of implementing and assessing-evaluating 
Tarwiyah, S., Dewi, N. M., \& Syukur, F. (2021). Portfolio assessment in the frame of multi-layered peer coaching: An alternative portfolio for pre-service teachers. EduLite: Journal of English Education, Literature, and Culture, 6 (2), 270-286. http://dx.doi.org/10.30659/e.6.2.270-286

competences. The achievement above represents the meaningfulness of the class.

\section{Post Course Curriculum Vitae}

Curriculum vitae is a document highlighting someone's professional and academic history in detail. It is a detailed biographical overview of the owner's education, professional experience, and other information that demonstrates the person's professional qualifications.

Figure 10 and 11 provide a sample of achievement in pre- and post-course $\mathrm{CV}$. Compared with CV 1, CV 2 implies the development of hard and soft skills of the owner.

The difference lies on achievements. CV 1 only lists five, whereas CV two lists eleven. Within one semester, six additional achievements are made. The achievements represent the owner's soft and hard skills, which support his competences as a pre-service teacher. The comparison is shown in the figures below.

\section{ACHIEVEMENTS \\ The 3rd winner of English Group Debate in Semarang Regency (2012) \\ - Paskibra of Kota Salatiga (2014) \\ - Chairman of Saka Bhayangkara Polres Kota Salatiga (2014 - 2015) \\ - Vice Coordinator of Publication, Walisongo English Club (2018 - 2019) \\ - Local Volunteer of AIESEC in Semarang (Winter and Summer 2019)}

Figure 10. The Achievement in CV 1

\section{ACHIEVEMENTS}

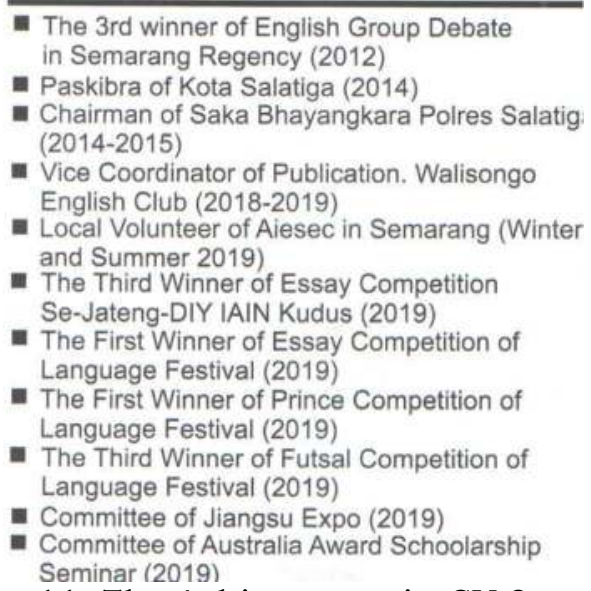

Figure 11. The Achievement in CV 2

One of the indicators of the improvement of the pre-service teachers' soft and hard skill is the addition of their experiences in terms of joining organization, internship, events or competition, passing skill courses, etc. the skills support the success of doing their job as teachers.

One of the skills demanded in this era is Information and Communication Technology (ICT). In line with industry revolution, $21^{\text {st }}$ century learning also considers the contribution of technology to educational field, there is an education platform called Education 4.0. This platform focuses on learning management which helps students improve their skills through implementing a new technology resulting from the society change (Puncreobutr, cited in Anggraeni, 2018). Consequently, teachers and students must be familiar with new technology. An investigation carried out by Fitriah (2018) through interviewing $201 \mathrm{EFL}$ teachers discovered that the teachers were aware of the importance of technology to help them explore their creativity and to encourage learners' creativity in a way that it helped transfer their creativity. Alberth, Mursalim, Siam, Suardika, \& Ino (2018) also argued that social media and its facets open up new conduit for sustainable life-long learning. 
The integration of $21^{\text {st }}$ century skills mainly deals with learning ability and innovation comprising critical thinking, problem solving, innovation, creativity, communication, and collaboration (Wang, 2014, cited in Asowayan et al., 2017). Integrating the skills, teachers need to be good at designing and implementing student-centered learning, employing information technology to facilitate learning. Teachers must be prepared for more complex work environment, have good literacy in the use of information and communication technology. Hence, participating actively in learning communities is advisable to tap their competence, "to embrace career-long learning as part of their professional ethics" (Gearhart 2010, cited in Asowayan et al., 2017). The pre-service teachers' experiences joining events, competition, internship, etc. is a kind of joining learning community. Many lesson learnts make them knowledgeable, skillful, and psychologically mature.

In addition, Learnovation (Hakim, 2018) reminds some skills that have to be considered in the twenty-first century workplace. Such skills are personal skills (initiative, resilience, responsibility, risk-taking and creativity), social skills (teamwork, networking, empathy and compassion) and learning skills (managing, organizing, and metacognitive skills). The skills may be maximally got from their experiences joining positive activities in any supporting community.

\section{CONCLUSION}

This study presents general overview of portfolio artifacts in EFL Micro Teaching class which implements Multi-layered Peer Coaching (MPC). The assessment is employed in the pre-, main, and post course. Most of the artifacts results in collaboration activities through peer learning, peer teaching, and peer correction, which are parts of MPC. In the pre-course, the pre-service teachers completed pre-course self-preparedness, targets of learning, and pre-course CV. In the main course, they compiled, observation report of teaching skill and teaching method demonstration, peer-corrected lesson plans, observation of teaching demonstration, reflection of teaching demonstration, lesson learnt from teaching practitioner, and lesson learnt from senior. In the post course, they collect their post course self-preparedness, learning target achievement, and post course CV.

Multilayered Peer Coaching (MPC) provides opportunity to the teachers to complete their reflective educational work in pairs before individual practices are given. The relationship between pre-service teachers in MPC is made in such a way so that they can work as coworkers who care, listen, and complete each other. MPC facilitates the EFL pre-service teachers' pedagogical knowledge and content knowledge, which supports an effective EFL learning.

\section{REFERENCES}

Alberth, A., Mursalim, M., Siam, S., Suardika, I. K., \& Ino, L. (2018). Social media as a conduit for teacher professional development in the digital era: Myths, promises or realities?. Teflin Journal, 29(2), 293-306. https://doi.org/10.15639/teflinjournal.v29i2/293-306 
Tarwiyah, S., Dewi, N. M., \& Syukur, F. (2021). Portfolio assessment in the frame of multi-layered peer coaching: An alternative portfolio for pre-service teachers. EduLite: Journal of English Education, Literature, and Culture, 6 (2), 270-286. http://dx.doi.org/10.30659/e.6.2.270-286

Anderson, L. W., Krathwohl Peter W Airasian, D. R., Cruikshank, K. A., Mayer, R. E., Pintrich, P. R., Raths, J., \& Wittrock, M. C. (2001). Anderson, L. W. (2001). Krathwohl. DR (Ed.), Airasian, PW, Cruikshank, KA, Mayer, RE, Pintrich, PR, Raths, J., \& Wittrock, MC, 214. Taxonomy for assessing a revision of Bloom's Taxonomy of educational objectives. https://www.uky.edu/ rsand1/china2018/texts/Anderson-Krathwohl - A taxonomy for learning teaching and assessing.pdf

Anggraeni, C. W. (2018). Promoting Education 4.0 in English for Survival Class: What are the Challenges? Metathesis: Journal of English Language, Literature, and Teaching, 2(1), 12. https://doi.org/10.31002/metathesis.v2i1.676

Asowayan, A. A., Ashreef, S. Y., \& Aljasser, H. S. (2017). The Modern Trends and Applications in the Development of Academic Staff in the University of Maryland \& George Mason University. English Language Teaching, 10(10), 102. https://doi.org/10.5539/elt.v10n10p102

Bryant, S. L., \& Timmins, A. A. (2002). Portfolio Assessment: Instructional Guide : Second Edition. Tai Po: Hongkong Institute of Education.

Butler, Y. G., \& Yeum, K. (2016). Dialogic competence of primary school English teachers in online peer coaching: A case study in South Korea. Journal of Asia TEFL, 13(2), 72-89. https://doi.org/10.18823/asiatefl.2016.13.2.1.72

Collet, V. S. (2015). The Gradual Increase of Responsibility Model for coaching teachers: Scaffolds for change. International Journal of Mentoring and Coaching in Education, 4(4), 269-292. https://doi.org/10.1108/IJMCE-06-2015-0017

Eastman, C. A. (2016). Coaching in organisations: how the use of fictional characters can develop coaching practice. International Journal of Mentoring and Coaching in Education, 5(4), 318-333. https://doi.org/10.1108/IJMCE-06-2016-0048

Efendi, Z., Usman, B. and Muslem, A. (2017). Implementation of portfolio assessment in teaching English writing. English Education Journal (Program Pascasarjana Universitas Negeri Semarang), 8(2), 187-198.

Fitriah. (2018). The role of technology in teachers' creativity development in english teaching practices. Teflin Journal, 29(2), 177-193. https://doi.org/10.15639/teflinjournal.v29i2/177-193

Gallagher, T. L., \& Bennett, S. M. (2018). The six "P" model: principles of coaching for inclusion coaches. International Journal of Mentoring and Coaching in Education, 7(1), 19-34. https://doi.org/10.1108/IJMCE-03-2017-0018

Hakim, M. L. I. (2018). Thinking maps - An effective viual strategy EFL/ESL for learners in 21 st century learning. LET: Linguistics, Literature and English Teaching Journal, $8(1), 1-14$.

Joh, J. (2019). Impact of Peer Feedback on Learning: A Case of EFL Teacher Trainees. The Journal of Asia Tefl, 16(4), 1103-1118.

Johns, J. L., \& Van Leirsburg, P. (1992). How professionals view portfolio assessment. Reading Research and Instruction, 32(1), 1-10. https://doi.org/10.1080/19388079209558101 
Joshi, M.K., Gupta, P. \& Singh, T. (2015). Portfolio-based Learning and Assessment. Indian Pediatric, 5, 232-235.

Matra, S., \& Rukmini, D. (2017). Issues and Challenges of E-Portfolio in Micro Teaching Class: Students' Perspectives. Arab World English Journal, 8(2), 238-251. https://doi.org/10.24093/awej/vol8no2.17

Miles, M. B. \& Huberman, A. M. (1994). Qualitative Data Analysis: A Source Book of New Methods. In Newbury Park, CA: Sage.

Mubarok, H. (2017). Students' Perception toward the Implementation of PeerAssessment in Writing; Before and After Revision. Celt: A Journal of Culture, English $\begin{array}{llll}\text { Language } \quad \text { Teaching } \quad \& \quad \text { Literature, } & 17(1),\end{array}$ https://doi.org/10.24167/celt.v17i1.1136

Musarokah, S. \& Egar, N. (2017). Students' Response s to the Application of PeerEditing Group Correction for Cause - Effect Written Assignments. Celt: A Journal of Culture, English Language, Teaching \& Literature, 17(2), 197-208.

Rotherham, A. J., \& Willingham, D. (2009). 21st Century Skills: The Challenges Ahead What Will It Take? Educational Leadership, 67(1), 16-21.

Shaw, D. (2017). Accomplished teaching: Using video recorded micro-teaching discourse to build candidate teaching competencies. In Journal of Interactive Learning Research (Vol. 28).

Tarwiyah, S., Warsono, W., Linggar Bharati, D. A., \& Sutopo, D. (2018). Professional Learning through Coaching: toward the Enhancement of the Teachers' Pedagogical Competence. Arab World English Journal, 9(4), 407-419. https://doi.org/10.24093/awej/vo19no4.30

Valencia, S.W. \& Calfee, R. (1991). The Development and Use of Literacy Portfolios for Students, Classes, and Teachers. Applied Measurement in Education, 4(4), 333345. https://doi.org/10.1207/s15324818ame0404

Yin, R. K. (2003). Case study research design and method. New Delhi: Sage Publication.

Yusuf, Y. Q., Silviyanti, T. M., \& Tauhidah, R. (2016). Looking Into the Efl Students Type of Feedbacks on Peer Correction Activity. Celt: A Journal of Culture, English $\begin{array}{llll}\text { Language Teaching } \& \text { Literature, } & \text { 16(1), }\end{array}$ https://doi.org/10.24167/celt.v16i1.563

Conflict of Interest Statement: The authors declare that the research was conducted in the absence of any commercial or financial relationships that could be construed as a potential conflict of interest.

Copyright (C) 2021 Tarwiyah, Dewi, and Syukur. This is an open-access article distributed under the terms of the Creative Commons Attribution License (CC BY). The use, distribution or reproduction in other forums is permitted, provided the original author(s) and the copyright owner(s) are credited and that the original publication in this journal is cited, in accordance with accepted academic practice. No use, distribution or reproduction is permitted which does not comply with these terms. 